Studia Psychologica, Vol. 63, No. 1, 2021, 5-23

https://doi.org/10.31577/sp.2021.01.811

\title{
Predictors of Teacher Burnout in Middle Education: School Culture and Self-Efficacy
}

\author{
Meral Öztürk ${ }^{1}{ }^{(\mathbb{D})}$, Meryem Berrin Bulut ${ }^{2}{ }^{(\mathbb{D})}$, Murat Yildiz $^{3}$ \\ ${ }^{1}$ Social Work, Sivas Cumhuriyet University, Sivas, Turkey \\ ${ }^{2}$ Psychology, Sivas Cumhuriyet University, Sivas, Turkey \\ ${ }^{3}$ Social Work, Sivas Cumhuriyet University, Sivas, Turkey
}

This study aimed to investigate the extent to which school culture and self-efficacy predicts teacher burnout. The research was conducted on $284\left(\mathrm{M}_{\text {age }}=36.15, \mathrm{SD}_{\text {age }}=8.34 ; 51.4 \%\right.$ females $)$ middle school teachers from 12 Turkish middle schools. The data were collected utilizing the School Culture Scale, Teachers' Sense of Efficacy Scale, Maslach Burnout Inventory and personal information form. Structural equation model was used to analyze whether school culture and self efficacy predicts teacher burnout or not. Findings showed that school culture dimensions of bureaucratic culture and task culture had a statistically significant positive association with efficacy for student engagement and efficacy for instructional strategies. Task culture had also a significant positive association with efficacy for classroom management. Although success culture was negatively associated with both emotional exhaustion and depersonalization, bureaucratic culture had a positive association with depersonalization. Efficacy for student engagement was negatively associated with emotional exhaustion. The results of this study support the importance of school culture for self-efficacy and burnout. The findings were discussed within the scope of burnout literature.

Key words: burnout, culture, school culture, self-efficacy, teacher

\section{Introduction}

Occupational stress is a common global problem of contemporary work life. Most workers may experience it at various levels in their work environment (Grayson \& Alvarez, 2008).
Long-term occupational stress may lead to chronic exhaustion that closely correlates with the burnout syndrome (Jennett, Harris, \& Mesibov, 2003; Smetackova, 2017).

The burnout concept was first introduced and defined in the 1970s by American Psychologist Herbert Freudenberger (Schaufeli,

Correspondence concerning this article should be addressed to Meryem Berrin Bulut, Psychology, Sivas Cumhuriyet University, Sivas, Turkey. E-mail: berrin_teke@yahoo.com

Supplementary information for this article can be accessed at https://journals.savba.sk/index.php/studiapsychologica/article/view/122

Received September 29, 2019 
Leiter, \& Maslach, 2009). Since then, it has been extensively researched by different disciplines, but any standard definition of the concept has not been achieved yet due to its complex, continuous, and heterogeneous construct (Maslach, Jackson, \& Leiter, 1996). Researchers from different disciplines have attributed different meanings to the term (see Farber, 1990; Maslach \& Jackson, 1981; Pines \& Aronson, 1988; Roloff \& Brown, 2011; Schaufeli \& Enzman, 1998). Among these definitions, the most widely accepted and used one comes from Maslach and Jackson (1981), who define burnout as a syndrome of emotional exhaustion that occurs frequently among people who work in some capacity with people. This conceptualization underlines three dimensions of burnout: Emotional exhaustion, depersonalization and personal accomplishment. When people's emotional resources run out, they feel exhausted. This kind of burnout stems from work overload and personal conflict at the workplace. If one feels emotionally exhausted, one no longer has sufficient energy to face another day or another person in need. As a result of depersonalization, people feel negative and behave pessimistically towards their colleagues. The overload of emotional exhaustion and self-protective instinct cause this type of burnout. Finally, low personal accomplishment refers to a tendency of self-criticism and dissatisfaction with one's working capacity. This kind of burnout emerges due to the lack of social support and opportunities for self-development in the workplace (Maslach \& Jackson, 1981).

Substantial number of research studies have revealed the prevalence of burnout syndrome in teaching (Guglielmi \& Tatrow, 1998; Johnson, Cooper, Cartwright, Donald, Taylor, \& Millet, 2005; Kyriacou, 2000; Maslach \& Schaufeli, 1993; McCarthy, Lambert, O’Donnell, \& Melendres, 2009; McGuire, 1979;
Stoeber \& Rennert, 2008; Tomić, Evers, \& Brouwers, 2004; Troman \& Woods, 2001). Teachers experience burnout when they feel that they are unable to meet the physical and emotional needs of their students, display cynical attitudes towards students, parents and the workplace and feel that they can no longer contribute to students' development (Maslach et al., 1996 cited in Grayson \& Alvarez, 2007).

Burnout among teachers results in serious physiological, psychological and social problems by increasing their anxiety, anger, boredom, guilt feelings, chances for nervous breakdown and disturbing their everyday activities, mood and social relations with others (Dimitrios \& Konstantinos, 2014; Friedman, 1991); causing them to neglect the preparation of their classes (Friedman, 1991); decreasing their self-confidence, causing low motivation (Schonfeld, 2001); triggering depression (Schonfeld, 2001); reducing job satisfaction (Skaalvik \& Skaalvik, 2009); leading to premature retirement (Baker \& Schaufeli, 2000) and changing attitude and personality (Schwarzer \& Greenglass, 1999).

Individual factors such as age, sex, marital status, education, tenure (Mojsa-Kaja, Golonka, \& Marek, 2015), self-esteem and self-efficacy (Brouwers \& Tomic, 2000) and situational factors like workload, excessive paperwork, lack of social support from colleagues and administrators, role conflict and ambiguity, low salary, student misbehavior, difficult relationships with parents, time pressure, low motivation of pupils (Burke \& Greenlass, 1993; Friedman, 1991; Kokkinos, 2007; Kyriacou, 1998; Kyriacou, 2001; Schonfeld, 2001; Skaalvik \& Skaalvik, 2011; Stoeber \& Rennert, 2008), poor working conditions, school climate, school culture and job characteristics (Mojsa-Kaja et al., 2015; Torfi, Alam, $\&$ Nikbakhsh, 2014) have all been marked as 
exhaustion factors among teachers. Among these factors, the impact of school culture and self-efficacy have been frequently studied in burnout research (Friedman, 1991).

\section{Teacher Burnout and School Culture}

Organizational culture is seen as a fundamental element of organizations (Zamini, Zamini, \& Barzegary, 2011) since it affects all organizational functions (Torfi et al., 2014). Mainly, the term is defined generally as 'common meanings shared by organizational members' (Torfi et al., 2014). Values, visions, norms, plans and practices are all part of the organizational culture (Kaplan \& Owings, 2013). Organizational culture affects organizational behaviors and shapes the work climate and work strategies (Balay \& İpek, 2010).

Like every organization each school has its own culture (Peterson, 2002). Factors such as personalities of the school members, the demographic background of the students, national cultural values, attitudes of school principals, etc., constitute school culture (Rahiem, Abdullah, \& Rahim, 2012).

Terzi (2005) has divided school culture into "support culture, bureaucratic culture, success culture, and task culture" by adapting the classifications in the international literature to the Turkish culture. Support culture refers to the school environment where mutual interactions and trust among employees are prioritized. In bureaucratic cultures there are rational standards and rules. Administrators strictly supervise the rules to keep the control of the organizations. In success cultures, individual success is more important than obeying the rules. Schools adopting success culture prefer to work with qualified employees. In task cultures, the organization's goal is prioritized rather than the individual's aim.

The relationship between school culture and burnout has been revealed in various research studies. For instance, Dimitrios and Konstantinos (2014) have found that schools, which are highly organized and dominated by success culture, increase burnout. Peterson (2002) have showed that schools dominated by positive, collaborative or supportive school culture, reinforce learning, commitment and motivation of teachers and decrease the feeling of burnout. Hence, in these schools the burnout level is low. Friedman (1991) has found a direct relation between school culture and burnout. He informed that the drive toward measurable goal-achievement behavior imposed on teachers by school principles, distrust of teachers' professional skills, circumscribing school culture, and disagreeable physical environment all contributed to teacher burnout. Likewise, Zamini et al. (2011) have revealed that job exhaustion is high in comprehensible culture groups. That is, the participative organizational culture has the lowest job burnout among other kinds of cultures. In their study, Torfi et al. (2014) have found significant negative correlation between organizational culture and burnout. In an organization dominated by powerful cohesiveness, communication and innovation, job burnout is low.

\section{Teacher Burnout and Self-Efficacy}

Self-efficacy, based on the theoretical framework of the Social Cognitive Theory, can be defined as individual belief in the ability to plan, organize and perform professional working roles (Bandura, 1994). This definition implies that self-efficacy is not about how many skills and competencies one has, but it is about a person's belief in what he/she can do with what he/she owns (Coladarci, 1992). Even if the person has sufficient knowledge, skills and abilities, he/she may not be aware of them or may have doubts about them, causing him/ her to not even attempt to perform the task. 
Thus, in order to perform a particular task, one should believe in one's knowledge, skills and abilities required. A sense of self-efficacy motivates individuals to continue their task in spite of mishaps. Besides, it ensures more willingness to do the task, and work harder and longer toward accomplishment. A person with high self-efficacy links his/her failure to deficient effort or to other variables such as the use of improper knowledge and skills. On the other hand, people with low self-efficacy are not able to accomplish their duties requiring effort, continuity and perseverance (Bandura, 1993). Employees with low self-efficacy presumably have negative thoughts about their future success and self-improvement (Luszczynska, Scholz, \& Schwarzer, 2005).

Self-efficacy is important in education as well as in other fields. Cherniss (1993) states that teacher self-competence contains the ability to fulfill professional requirements, determining teaching stages, fulfilling duties and procedures related to school management, being part of the school, and completing social and political processes in the school environment. If a teacher believes that his or her knowledge, skills and experience in these areas are sufficient, it means that he or she has high sense of self-efficacy. Self-efficacy has a significant role in overcoming hard situations effectively during professional life. Teachers with high self-efficacy can cope with the problems that they come across at schools (Bandura, 1993/1995).

A great deal of research revealed that high level of teachers' self-efficacy is related to effectiveness, self-concept, commitment, personality, and well-being (Yulianti, Atomzeal, \& Arina, 2018). When teachers with high self-efficacy face problems related to their job, they focus on these problems and work to solve them. In contrast, teachers with low self-efficacy avoid such problems and strive to resolve their emotional discomfort in their inlying world. Such a situation increases the exhaustion risk of teachers (Friedman, 1991; Savaş, Bozgeyik, \& Eser, 2014; Skaalvik \& Skaalvik, 2010; Schwarzer \& Hallum, 2008). In other words, if teachers have high level of self-efficacy, they develop positive attitudes towards students and education systems (Bandura, 1997). Contrarily, low level of self-efficacy is linked to anxiety. Thus it can be concluded that self-efficacy is one of the coping resources against anxiety and burnout (Schwarzer \& Greenglass, 1999). The meta-analysis of 57 original studies gave an estimate of the average effect of -.33 for the relationships between self-efficacy and burnout $(r=-.33)$. The average impact estimate between self-efficacy and emotional exhaustion (-.31) is similar to the average impact estimate for the relationship between self-efficacy and depersonalization (-.33). The greatest estimate of the average effect of - .49 was found for the relationship between self-efficacy and decreased personal success (Shoji, Cieslak, Smoktunowicz, Rogala, Benight, \& Luszczynska, 2015).

\section{Self-Efficacy and School Culture}

The relationship between school culture and self-efficacy has been confirmed in some studies. For example, Guenther (2014) found a significant correlation between teachers' perceptions of their working conditions and self-efficacy. In their study with doctors, nurses and other staff members in hospitals, Kilıç, Seymen, and Grobowski (2014) have revealed that self-efficacy has statistically significant relationships with organizational culture. However, this relationship between self-efficacy and organizational culture is mutual. That is, change in one leads to change in the other (Bandura, 1994/1997).

Creating a healthy and productive learning environment depends on self-efficacy level of teachers. If teachers have high self-efficacy 
level they develop positive attitudes towards students and education systems (Bandura, 1997). High self-efficacy enhances environmental change and personal conformation. Teachers with high self-efficacy will take part in changing the negative environmental structure. If they fail to accomplish this, they will seek another organization with better circumstances; however, those with low self-efficacy will react to negative environment with resignation and cynicism. But self-efficacy is not sufficient for lessening burnout when the organizational structure is excessively punitive, unfair and unresponsive (Cherniss, 1993). Bandura (1997) claims that "Individuals are born without their efficacy perceptions; this perception develops as a result of individual's interaction with his/her environment along a time". It means that environmental conditions are the main sources of teachers' self-efficacy perceptions. Thus, it can be concluded that self-efficacy is context dependent. For instance, in schools with democratic culture, each person's views, contributions and opinions are regarded as important. These kinds of institutions encourage teachers to be more successful in doing their jobs. As a result, teachers become more enthusiastic about being successful in their jobs and also, their perceptions of self-efficacy are expected to be positive (Bandura, 1997; Kılıç et al., 2014). On the other hand, in schools with power culture, teachers' self-efficacy perceptions are expected to be negative, since power and authority are solely in the hands of the organizational leader who is in charge of everything. In these cultures, where inequality and hierarchy are dominant, members of the organizations are not encouraged enough to carry out their responsibilities (Hofstede, 1983 cited in Kılıç et al., 2014). Sottile, Carter, and Murphy (2002) have shown that high self-efficacy develops through encouraging positive social interactions.

\section{The Present Study}

Self-efficacy is one of the coping resources against burnout which has attracted most attention, being also the most significant internal resource. As mentioned above, lack of self-efficacy is linked to anxiety (Schwarzer \& Greenglass, 1999). Social support is another coping resource against burnout. Social support is related to the functional value of social relations, especially their supportive side in times of need (Schwarzer \& Greenglass, 1999). This corresponds to school culture. Based on these relations, this study aimed to examine the extent to which school culture and self-efficacy predicts teacher burnout. For this purpose, structural equation modeling was used. In creating the model, the associations are based on the information that burnout has some antecedents (e.g., individual and situational factors) (Brouwers \& Tomic, 2000; Mojsa-Kaja et al., 2015). Self-efficacy, as the 'individual factor' and school culture, as the 'situational factor', are taken into the equation. Although considerable efforts have been devoted to understand the nature of relationships between school culture and self-efficacy, self-efficacy and burnout, and school culture and burnout, they seem to remain unsatisfactory because these binaries have been examined independently from each other. However, recent studies have revealed that burnout is not tied to a single cause, but to a combination of different factors (Gündüz, 2006). Therefore, Kokkinos (2007) states that teachers' personal parameters and stress factors should be kept in mind when examining the burnout phenomenon. With these explanations, this study simultaneously explores the effects of personal and situational factors on burnout. By examining the associations between the variables within a model, this study intended to fill the gap in the national 
and international burnout literature, since as far as we know, a study considering the association among school culture, self-efficacy and burnout has not been conducted yet.

This study is intended to assist middle education practitioners and institutions in their pursuit of decreasing burnout. The Turkish middle school educational system includes a general education middle school and a religious vocational middle school that provide compulsory and formal education. The public general education middle schools provide free education opportunities for students. Private general education middle schools, on the other hand, are owned by a natural person and education is given in return for certain fee. Nevertheless, they are under the control of the state. Education in both middle schools is based on positive science courses such as chemistry, physics and mathematics. The religious vocational middle schools are owned by the state only. They provide religious education in addition to the general curriculum given at public middle schools. Students in these schools learn the basic sources and methods of Islam in depth. In this context, they take courses such as the life of the Prophet Muhammad, Arabic, Quran and other courses giving basic religious information. At the end of the 8 th grade, the entrance examination for high school is administered. With this examination held annually, students are enrolled in high schools. Those who pass the high school entrance exam are enrolled in high schools with high level of success; those who fail to pass this exam can go to relatively low-achieving high schools. Thus, the stage between $5^{\text {th }}$ and $8^{\text {th }}$ grade is very important not only for both students and their parents but also for teachers in these schools. For this reason, especially the secondary school teachers were selected for this study. When the impact of different dimensions of school culture on self-efficacy and burnout are examined, the concept of this study can provide a broader view of how teacher-school relationships can become positive and be maintained. These relationships can be efficient both in the short and long term in the middle schools.

Based upon the previous work on the dynamics of school culture, self-efficacy and burnout, we developed and tested a hypothesized model (see Figure 1). Hence, we proposed the following hypotheses.

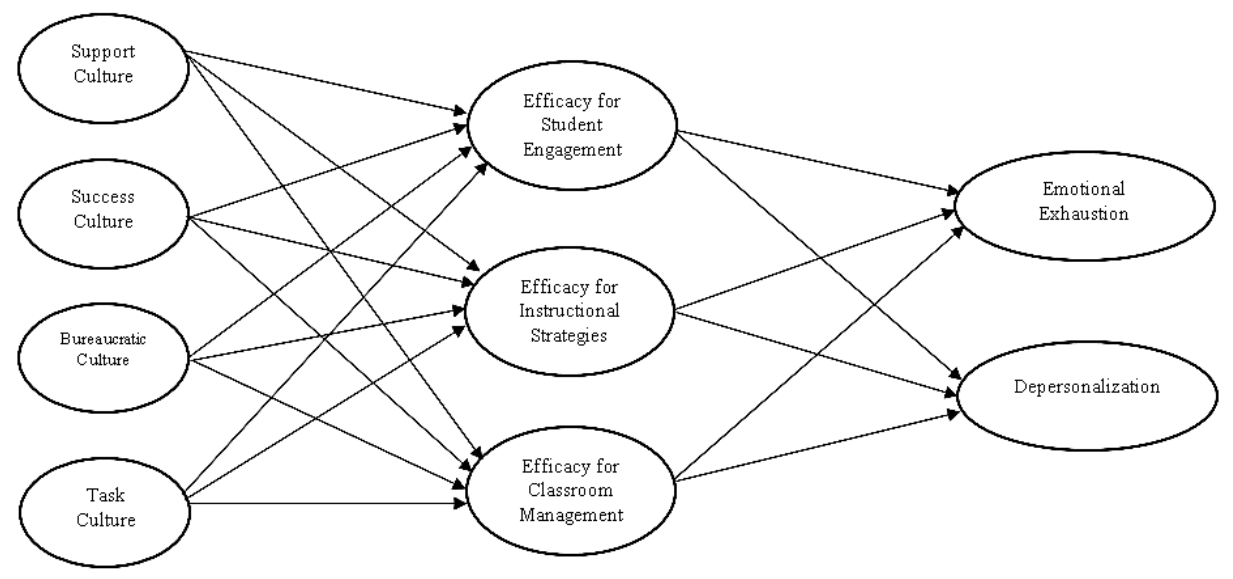

Figure 1 Hypothesized model 
$H_{1}$ Support, success and task culture are positively associated with self-efficacy but bureaucratic culture is negatively associated with self-efficacy.

$\mathrm{H}_{2}$ Self-efficacy dimensions are negatively associated with burnout dimensions.

$\mathrm{H}_{3}$ Bureaucratic and success cultures are positively associated with burnout while support and task cultures are negatively associated with burnout dimensions.

For reasons of clarity, direct relations between school culture dimensions and burnout dimensions are not shown in Figure 1.

\section{Methods}

\section{Participants}

In this study, we had 284 middle school teachers' voluntary participation. Participants were selected according to convenience and snowball sampling, which are non-probability sampling techniques. There were 146 (51.4\%) females and $138(48.6 \%)$ males in the sample. The mean age of the participants was 36.15 years $(S D=$ 8.34; Range $=22-65)$. $80.3 \%$ of the participants were married ( $n=228), 70.36 \%$ ( $n=197)$ were working at public middle school, $15 \%$ at religious vocational middle school and $14.64 \%$ at private middle school. 93\% $(n=264)$ of them intentionally chose their profession. The vast majority of the participants graduated from the faculty of education (71.5\%) with a Bachelor's or Master's degree (74.3\%). Most of the participants' partners are $(65.8 \%)$ working. The mean tenure in the current school is 4.40 years $(S D=3.56)$ and the mean tenure of their profession as teachers is 12.68 years $(S D=8.13)$. The mean of weekly course hours is 24.93 hours $(S D=6.46)$.

\section{Instruments}

To measure school culture, self-efficacy and burnout, psychometrically valid and reliable instruments were used. For this purpose, the data were collected utilizing three scales and one personal information form. More information about the scales and personal information form are given below.

School Culture Scale (SCS): This scale was developed through exploratory factor analysis by Terzi (2005) to measure the different kinds of school cultures. The confirmatory factor analysis for this scale was conducted by Kılıç (2018). The instrument has 29 items and four subscales: Support (e.g., 'Employees share their joys and sorrows.'), success (e.g., 'Working for professional purposes is appreciated.'), bureaucratic (e.g., 'Hierarchy is important.'), and task cultures (e.g., 'Enough efforts are made to achieve the goals of the school'). A five-point Likert type scale ranging from ' 1 = never to $5=$ always' was used. Cronbach's Alpha values of the subscales were .88 for the support culture, .82 for the success culture, .76 for the bureaucratic culture, and .74 for the task culture. In the present study, the Cronbach's Alpha and split-half values were $.81 / .80$ for support culture, $.74 / .77$ for success culture, $.75 / .76$ for bureaucratic culture, and .73./.75 for task culture.

Turkish Teachers' Sense of Efficacy Scale (TTSES): Teachers' Sense of Efficacy Scale (TSES) was developed by Tschannen-Moran and Hoy (2001) to assess the sense of efficacy of teachers and adapted to Turkish through the use of confirmatory factor analysis and Rasch measurement by Çapa, Çakıroğlu, and Sarıkaya (2005). It consists of 24 items and three subscales: Efficacy for student engagement - SE (e.g., 'How far can you achieve reaching hard-to-work students?'), efficacy for instructional strategies - IS (e.g., 'How well can you answer students' difficult questions?'), and efficacy for classroom management - CM (e.g., 'How much can you ensure to control the behaviors that negatively affect the lesson in the classroom?'). It is rated with a nine-point Likert type scale ranging from 
' 1 = never to $9=$ always'. The coefficient Alpha values were .82 for SE, .86 for IS, and .84 for $\mathrm{CM}$. The reliability of the whole scale was .93 . In this study, the internal consistency coefficient and split-half values were $.89 / .88$ for SE, $.90 / .88$ for IS, and $.91 / .88$ for CM. The reliability of the whole scale was $.96 / .93$.

The Maslach Burnout Inventory (MBI): The original scale was developed by Maslach and Jackson (1986) to measure levels of burnout and adapted to Turkish through exploratory factor analysis with varimax rotation by Ergin (1993). MBI for Human Services version was used in this study since this version is widely used in Turkey. The authors have license rights to MBI from MindGarden. There are 22 items and three subscales: Emotional exhaustion (e.g., 'I feel emotionally drained from my work.'), depersonalization (e.g., 'I feel I treat some recipients as if they were impersonal objects.'), and personal accomplishment (e.g., 'I deal very effectively with the problems of my recipients.'). The inventory is evaluated with a five-point Likert type scale from ' 1 = never to $5=$ everyday'. Cronbach's Alpha was .83 for emotional exhaustion, .65 for depersonalization, and .72 for personal accomplishment. In the current study, the Cronbach's Alpha and split-half values were .79/.70 for emotional exhaustion, .71/.71 for depersonalization, and $.49 / .50$ for personal accomplishment. Because of the unacceptable reliability values of personal accomplishment, this factor was extracted from structural analysis.

Personal Information Form: This form is developed by researchers in order to get information about gender, age, marital status, school, education, tenure and weekly course hours of the participants.

\section{Procedure}

Before conducting the study, the research permission was obtained from Sivas National
Education Directorate. Ethical permission was received from Sivas Cumhuriyet University Social Science Ethical Committee. According to the information obtained from Sivas $\mathrm{Na}$ tional Education Directorate, in the academic year of 2018-2019, there were 66 middle schools (regular or religious/public or private) in which 1769 teachers were employed in the center of Sivas. In the first stage, the convenience sampling technique was used in determining the sample. In this frame, 5 schools were visited by researchers. The questionnaires were distributed to the teachers who agreed to participate in the survey. Teachers were given three days to complete the questionnaire. After 3 days, researchers collected the questionnaires.

The participants were informed that there were no right or wrong answers to the items, as long as the answers reflected their personal ideas. The survey took about 15 minutes to complete. Informed consent was obtained from all participants. The responses were treated anonymously.

In the second stage, the snowball technique was preferred to reach the sample. The researchers visited 7 schools with the guidance of the school principals who were visited before. Thus, the data were collected from a total of 12 middle schools of which 3 were private and 9 were public schools. As a result, researchers aimed to reach all types of schools in the Turkish education system, so the diversity/heterogeneity of the sample was provided for. A total of 310 questionnaires were distributed to the teachers and 288 of them were returned. 4 questionnaires were excluded from the analysis as they were not fully or adequately completed.

\section{Analysis}

In the analysis process, the descriptive and inferential analysis techniques were used, 
and the data were analyzed by SPSS25 and AMOS24. Using the AMOS24 structural equation, modeling with eight latent constructs was performed to analyze the data based on the hypothesized model. The Bentler-Weeks Model specification method was utilized (Bentler \& Weeks, 1980). For processing data path model with both latent factors and observed variables and covariance matrix were used.

\section{Results}

Before conducting the analysis, the data set is checked for missing data, outliers, normality and homogeneity of the variances. To check whether the scales have construct validity, confirmatory factor analysis was conducted. The fit indexes are: for school culture scale (RMR-Root Mean Square Residual = .06; IFI-Incremental Fit Index = .92; CFI-Comparative Fit Index = .92; RMSEA-Root Mean Square Error of Approximation $=.04$ ) for teacher sense of self-efficacy scale $(\mathrm{RMR}=.07 ; \mathrm{IFI}=$ .93; $\mathrm{CFI}=.93$; $\mathrm{RMSEA}=.07$ ) and for burnout scale $(\mathrm{RMR}=.08 ; \mathrm{IFI}=.91 ; \mathrm{CFI}=.90 ; \mathrm{RMSEA}=$ .06). These values indicate a good fit between the model and the observed data.

Since measurement errors put the validity of the findings and the conclusions of a research at risk, researchers try to avoid these errors. Method biases are the basic causes of measurement errors. Common method bi- ases, which can be the result of the fact that the predictor variable and the criterion variable are provided by the same person, can affect the correlation observed among the measures. One of the frequently used methods to test the common method bias is the Harman's single factor test. The findings have shown that there is no common method bias (explained variance $18.46 \%$ ) in this study.

Before conducting SEM, researchers examined whether self-efficacy, school culture and burnout level of teachers differed in terms of school types in Turkish educational system. In order for researchers to be able to generalize the findings we carried out ANOVA analysis.

As shown in Table 1, there is a significant mean difference in efficacy for student engagement, efficacy for instructional strategies, efficacy for classroom management, bureaucratic culture and task culture. In student/ instructional efficacy, private schools differ significantly from both religious vocational schools and public schools. In classroom efficacy, private schools differ significantly from religious vocational schools. In bureaucratic culture, three school types differ from each other significantly. In task culture, private schools differ significantly from both religious vocational schools and public schools. On the other hand, burnout level is not different among teachers working in different types of schools.

Table 1 Mean differences in school types (ANOVA)

\begin{tabular}{|c|c|c|c|c|c|c|c|c|c|}
\hline & $\begin{array}{l}\text { School } \\
\text { Type }\end{array}$ & Mean & $S D$ & & $\begin{array}{l}\text { Sum of } \\
\text { Squares }\end{array}$ & $d f$ & $\begin{array}{c}\text { Mean } \\
\text { Squares }\end{array}$ & $F$ & $p$ \\
\hline \multirow[t]{3}{*}{$\begin{array}{l}\text { Emotional } \\
\text { exhaustion }\end{array}$} & Religious & 2.41 & .70 & $\begin{array}{l}\text { Between } \\
\text { Groups }\end{array}$ & .241 & 2 & .12 & .26 & .77 \\
\hline & Public & 2.34 & .68 & $\begin{array}{l}\text { Within } \\
\text { Groups }\end{array}$ & 127.004 & 277 & .46 & & \\
\hline & Private & 2.41 & .64 & Total & 127.246 & 279 & & & \\
\hline
\end{tabular}


Table 1 continued

\begin{tabular}{|c|c|c|c|c|c|c|c|c|c|}
\hline & $\begin{array}{l}\text { School } \\
\text { Type }\end{array}$ & Mean & $S D$ & & $\begin{array}{l}\text { Sum of } \\
\text { Squares }\end{array}$ & $d f$ & $\begin{array}{c}\text { Mean } \\
\text { Squares }\end{array}$ & $F$ & $p$ \\
\hline \multirow[t]{3}{*}{ Depersonalization } & Religious & 1.86 & .69 & $\begin{array}{l}\text { Between } \\
\text { Groups }\end{array}$ & 2.663 & 2 & 1.33 & 2.54 & .08 \\
\hline & Public & 1.91 & .71 & $\begin{array}{l}\text { Within } \\
\text { Groups }\end{array}$ & 145.108 & 277 & .52 & & \\
\hline & Private & 2.18 & .80 & Total & 147.771 & 279 & & & \\
\hline \multirow{3}{*}{$\begin{array}{l}\text { Efficacy for } \\
\text { student } \\
\text { engagement }\end{array}$} & Religious & 6.72 & .99 & $\begin{array}{l}\text { Between } \\
\text { Groups }\end{array}$ & 18.218 & 2 & 9.11 & 10.43 & .00 \\
\hline & Public & 6.83 & .95 & $\begin{array}{l}\text { Within } \\
\text { Groups }\end{array}$ & 241.987 & 277 & .87 & & \\
\hline & Private & 7.52 & .79 & Total & 260.205 & 279 & & & \\
\hline \multirow{3}{*}{$\begin{array}{l}\text { Efficacy for } \\
\text { instructional } \\
\text { strategies }\end{array}$} & Religious & 7.20 & 1.06 & $\begin{array}{l}\text { Between } \\
\text { Groups }\end{array}$ & 7.139 & 2 & 3.57 & 4.02 & .02 \\
\hline & Public & 7.38 & .93 & $\begin{array}{l}\text { Within } \\
\text { Groups }\end{array}$ & 245.930 & 277 & .89 & & \\
\hline & Private & 7.76 & .86 & Total & 253.069 & 279 & & & \\
\hline \multirow{3}{*}{$\begin{array}{l}\text { Efficacy for } \\
\text { classroom } \\
\text { management }\end{array}$} & Religious & 7.07 & 1.14 & $\begin{array}{l}\text { Between } \\
\text { Groups }\end{array}$ & 8.132 & 2 & 4.07 & 4.06 & .02 \\
\hline & Public & 7.27 & 1.00 & $\begin{array}{l}\text { Within } \\
\text { Groups }\end{array}$ & 277.672 & 277 & 1.00 & & \\
\hline & Private & 7.67 & .87 & Total & 285.804 & 279 & & & \\
\hline \multirow[t]{3}{*}{ Support culture } & Religious & 3.83 & .54 & $\begin{array}{l}\text { Between } \\
\text { Groups }\end{array}$ & 1.482 & 2 & .74 & 2.37 & 1.00 \\
\hline & Public & 3.69 & .56 & $\begin{array}{l}\text { Within } \\
\text { Groups }\end{array}$ & 86.733 & 277 & .31 & & \\
\hline & Private & 3.87 & .57 & Total & 88.214 & 279 & & & \\
\hline \multirow[t]{3}{*}{ Success culture } & Religious & 3.82 & .61 & $\begin{array}{l}\text { Between } \\
\text { Groups }\end{array}$ & .894 & 2 & .45 & 1.33 & .27 \\
\hline & Public & 3.71 & .59 & $\begin{array}{l}\text { Within } \\
\text { Groups }\end{array}$ & 93.198 & 277 & .34 & & \\
\hline & Private & 3.84 & .47 & Total & 94.093 & 279 & & & \\
\hline \multirow[t]{3}{*}{$\begin{array}{l}\text { Bureaucratic } \\
\text { culture }\end{array}$} & Religious & 2.96 & .43 & $\begin{array}{l}\text { Between } \\
\text { Groups }\end{array}$ & 11.595 & 2 & 5.80 & 19.36 & .00 \\
\hline & Public & 3.20 & .57 & $\begin{array}{l}\text { Within } \\
\text { Groups }\end{array}$ & 82.961 & 277 & .30 & & \\
\hline & Private & 3.68 & .53 & Total & 94.556 & 279 & & & \\
\hline \multirow[t]{3}{*}{ Task culture } & Religious & 4.07 & .49 & $\begin{array}{l}\text { Between } \\
\text { Groups }\end{array}$ & 4.195 & 2 & 2.10 & 7.44 & .00 \\
\hline & Public & 4.05 & .55 & $\begin{array}{l}\text { Within } \\
\text { Groups }\end{array}$ & 78.093 & 277 & .28 & & \\
\hline & Private & 4.40 & .49 & Total & 82.288 & 279 & & & \\
\hline
\end{tabular}

Note. $p<.05$ 
According to the results, there were significant correlations among support and success culture and burnout dimensions. While bureaucratic culture is significantly correlated to depersonalization, task culture is not significantly correlated to any burnout dimensions. All dimensions of teacher's self-efficacy are correlated to emotional exhaustion. Only efficacy for instructional strategies and efficacy for classroom management are correlated to depersonalization (see Table 2).

Then, structural equation modeling was performed to investigate the predictive effect of independent variables on burnout. The model was tested by using the Path analysis, and Figure 2 shows the path model diagram including statistically significant path loadings.

The structural equation model explained $7 \%$ of the variance in emotional exhaustion and $8 \%$ of the variance in depersonalization, $16 \%$ of the variance in efficacy for student engagement, $19 \%$ of the variance in efficacy for instructional strategies, and $13 \%$ of the variance in efficacy for classroom management.

Within the sample, bureaucratic culture and task culture had a statistically significant association with efficacy for student engagement $\left(b_{\text {bureaucratic }}=.15 ; b_{\text {task }}=.32\right)$ and efficacy for instructional strategies $\left(B_{\text {bureaucratic }}=.15\right.$;
$\left.B_{\text {task }}=.40\right)(p<.05)$. Task culture also had a statistically significant association with efficacy for classroom management $(B=.37$, $p<.05)$. However, support culture and success culture did not have any significant association with self efficacy. This finding shows that the first hypothesis is partially supported. As expected, task culture was positively associated with the self-efficacy dimensions. But, contrary to our expectation, bureaucratic culture is negatively associated with the self efficacy dimensions. Surprisingly, no relation was found between support culture, success culture and self efficacy dimensions.

Further examination of the structural model indicated that the second hypothesis is partially supported. That is, only success culture and efficacy for student engagement had a significant association with emotional exhaustion $\left(b_{\text {success }}=-.17 ; b_{\text {efficacy for student management }}=\right.$ -.23). On the other hand, efficacy for instructional strategies and efficacy for classroom management had no statistically significant association with burnout dimensions.

As for the relationship between school culture and burnout the following findings were found. Contrary to our expectations success culture was negatively related to depersonalization. On the other hand, as expected, bureaucratic culture had a significant association

Table 2 Pearson correlation coefficients

\begin{tabular}{lccccccccc}
\hline & 1 & 2 & 3 & 4 & 5 & 6 & 7 & 8 & 9 \\
\hline 1. Support culture & - & & & & & & & & \\
2. Success culture & $.76^{*}$ & - & & & & & & & \\
3. Bureaucratic culture & $.22^{*}$ & $.23^{*}$ & - & & & & & & \\
4. Task culture & $.42^{*}$ & $.42^{*}$ & $.36^{*}$ & - & & & & & \\
5. Efficacy for student engagement & $.22^{*}$ & $.19^{*}$ & $.30^{*}$ & $.37^{*}$ & - & & & & \\
6. Efficacy for instructional strategies & $.23^{*}$ & $.18^{*}$ & $.27^{*}$ & $.43^{*}$ & $.83^{*}$ & - & & & \\
7. Efficacy for classroom management & $.19^{*}$ & $.14^{*}$ & $.18^{*}$ & $.37^{*}$ & $.79^{*}$ & $.81^{*}$ & - & & \\
8. Emotional exhaustion & $-.19^{*}$ & $-.20^{*}$ & .09 & -.08 & $-.17^{*}$ & $-.14^{*}$ & $-.16^{*}$ & - & \\
9. Depersonalization & $-.16^{*}$ & $-.20^{*}$ & $.16^{*}$ & -.10 & -.07 & $-.14^{*}$ & $-.15^{*}$ & $.54^{*}$ & - \\
Mean & 3.73 & 3.74 & 3.24 & 4.10 & 6.91 & 7.40 & 7.29 & 2.36 & 1.95 \\
SD & .57 & .59 & .58 & .55 & .96 & .96 & 1.01 & .67 & .73 \\
\hline
\end{tabular}

Note. ${ }^{*} p<.05$ 


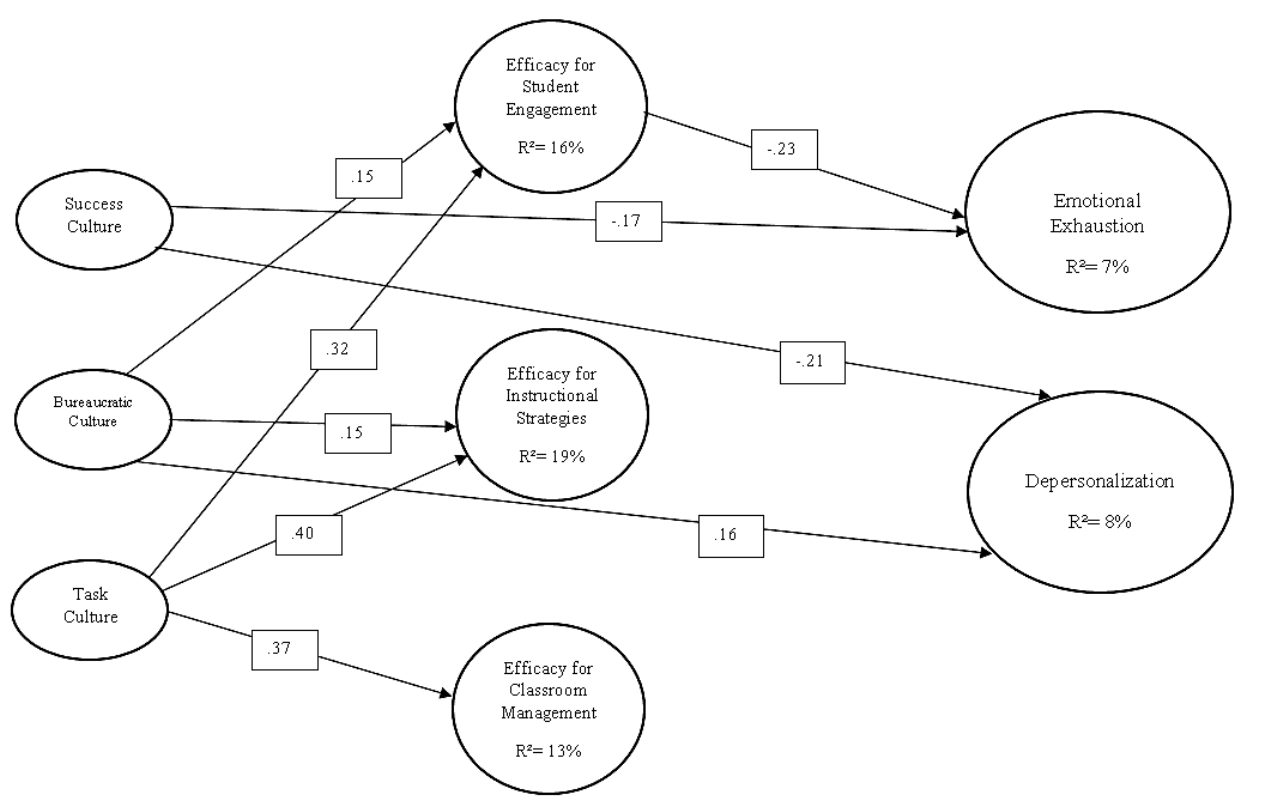

Figure 2 Path model and estimates, $p<.05$

with depersonalization $\left(B_{\text {success }}=-.21 ; B_{\text {bureaucratic }}=\right.$ $.16)$. The results show that the third hypothesis was partially supported.

In this study the following fit indexes are used: $\chi^{2}, \mathrm{CFI}, \mathrm{IFI}, \mathrm{NFI}$ (Normed Fit Index), TLI (Tucker-Lewis Index), RFI (Relative Fit Index) and RMSEA. $\chi^{2}=16.78, d f=8, p=.03$ indicates a good model fit $\left(2<\chi^{2}<3\right) . \mathrm{CFI}=.99$, IFI $=.99$, $\mathrm{NFI}=.98, \mathrm{TLI}=.97$ and $\mathrm{RFI}=.94$ shows good/ acceptable model fit (> .900). Lastly, RMSEA = .06 indicates an acceptable value $(<.08)$.

\section{Discussion}

The aim of the present study was to explore whether school culture and self efficacy predicts burnout or not. Some important findings are below:

First, the self efficacy level of private school teachers was found to be higher than that of teachers in other schools. This finding is plausible, since the high educational fee in private schools in Turkey means that the number of students is low. This may increase the chances of teachers in these schools to engage students in class participation. Besides, teachers in private school have a variety of materials to employ the appropriate instructional strategies. The administrators encourage them to participate in various seminars to support their development. All these opportunities may increase the teachers' self efficacy level in a positive way (Gençtürk \& Memiş, 2009). Furthermore, it was found that bureaucratic and task cultures were stronger in private schools compared to state schools.

Second, it has been found that, contrary to our expectations, bureaucratic culture had a positive association with sense of self efficacy. Some researchers argued that bureaucratic culture in the organization has a negative impact on self-efficacy since it restricts teaching capacities by hindering collaboration among teachers and reducing work motivation (e.g., 
Sinden, Hoy, \& Sweetland, 2004). In a similar vein, Kılınç, Koşar, Er, and Öğdem (2016) found that bureaucratic school structures and teacher self-efficacy were positively correlated. One may account for this on the ground that clear rules, regulations and roles for teachers in the bureaucratic school cultures may prevent them from experiencing role conflict and ambiguity (Kılınç et al., 2016), since ambiguity restricts a person to evaluate his/her ability to perform a task (Li \& Bagger, 2008). Additionally, as individuals have control and understanding over their environment this will result in the increase of self-efficacy (Gist \& Mitchell, 1992).

Furthermore, it has been indicated in our research that in accordance with our expectation, task culture was found to be significantly associated with all dimensions of self-efficacy. Likewise, Sesadri and Gloryson (2013) found that the self-efficacy level of employees working in institutions based on market culture, which had a similar goal to task culture, is high. One plausible explanation may be due to the fact that in the task culture, school administrators aim to increase teachers' motivation in line with school's objectives. Therefore, they try to increase teachers' commitment to school, which is possible through flexible hierarchical structuring. The flexible hierarchy may provide a positive work environment in which teachers can develop their capacities (Sesadri \& Gloryson, 2013). Additionally, commitment to teaching has a significant relation to self-efficacy (Chesnut \& Cullen, 2014).

Surprisingly, in this study, success culture emphasizing the success of teachers, had no association with any self-efficacy factors. However, many previous studies have shown that success culture leads to an increased level of self-efficacy (Bandura, 1994). Although a significant relation between success culture and all dimensions of self-efficacy was found in the correlation analysis, this association in the model could be due to the effects of other variables in the model, and also, this association may have been suppressed by these variables.

Third, only efficacy for the student engagement dimension of self-efficacy was found to be significantly associated with burnout. This sub-factor influences the emotional exhaustion dimension of burnout in a negative way. Burnout has a negative impact both on psychological and physical well-being, which leads to a variety of problematic behaviors (Huberman \& Vandenberghe, 1999). As 'conflicting expectations, increased work pressure, impractical innovations, unsupportive school environment and unmotivated or undisciplined pupils appear to affect a large number of the teaching force in both Europe and North America', the same case is valid for Turkey as well (Huberman \& Vandenberghe, 1999). Burnout is regarded as a contributing factor to the behavior and experience of teachers and students. Burnout is affected by many factors such as characteristics specific to social environment and school environment, nature of work, personal characteristics of teachers and students, etc. (Maslach \& Leiter, 1999). Contrary to our expectations, only the student engagement dimension of self-efficacy was negatively associated with the emotional exhaustion dimension of burnout. Instructional strategies and classroom management were not associated with any dimensions of burnout. The result confirms the idea that self efficacy has different associations with three components of burnout. Relationship differences may contribute to the debate on internal structure of burnout (Shoji et al., 2015).

The negative relation between student engagement and emotional exhaustion may be due to the fact that the middle school students are in the 11-14 age range. In this age range, they are entering adolescence from 
childhood. Adolescence is considered to be an intermediate stage in which one is neither a child nor an adult. In this stage, although individuals do not have their own social responsibilities, they can explore, test, and practice their roles (Cloutier, 1994). Kelleci (2008) mentions that adolescence is a complex period in which an individual tries to answer the following questions: how will the relationships with others be, how will their friendships continue and which way to follow in life. During this period, adolescents have to shape their own identities and their relations with other individuals as well as make important decisions about their futures. One of the most stressful events in this period for Turkish adolescents is the preparation for the transition exam for high schools. In this process, adolescents may feel pressure from both their parents and teachers, which causes a substantial source of stress. For all these reasons, it may be difficult for teachers to motivate students. As a result thereof, teachers, who do not have the competency to motivate students, are likely to experience emotional exhaustion.

No association among instructional strategies, classroom management and burnout may be due to the fact that instructional strategies and classroom management strategies are clearly determined by the Turkish Ministry of National Education and school administrators. Thus, teachers may have no room to deliberate about how they will behave in the classroom and what strategies they will adopt.

Fourth, the present study found that school culture and burnout were related. In this frame, success culture and bureaucratic culture have significant associations with the dimensions of burnout. Contrary to our expectations, task culture had no association with burnout. The significance of organizational culture as the cause of burnout has been confirmed theoretically and in practice in substan- tial research (Friedman, 1991). In previous studies (Korkmaz \& Çevik, 2017; Zamini et al., 2011), where the sample consisted of teacher candidates, teachers, and academicians, organizational culture had a statistically significant relation with burnout. This supports the idea that changing the environment is easier than changing people (Friedman, 1991). In schools where the culture of success is dominant, the teachers may be allowed to make personal decisions, establish social relationships with their colleagues, make frequent and important contributions to their organizations, thus, their perception of weakness, insignificance, isolation and alienation at school is nominal (Korkmaz \& Çevik, 2017). In line with our expectation, bureaucratic school culture was found to be positively associated with depersonalization. As is known, certain and clear standards and rules are found in hierarchical organizations. It is expected that employees should obey these rules. In this respect, administrators have a more authoritarian perspective in a bureaucratic culture (Terzi, 2005). Bureaucratic culture and authoritarian leadership may cause burnout among employees. The findings of some previous studies have confirmed this positive relationship between authoritarian leadership and burnout (see Haghani, Bahramiand, \& Sarkhosh, 2011; Pyc, Meltzerand, \& Lie, 2016).

In this study, while there exists no associations between task culture and burnout, there is a significant association between success culture and bureaucratic culture with burnout. The significance of both organizational and environmental factors as the cause of burnout has been confirmed theoretically and in practice in substantial research. This supports the idea that changing the environment is easier than changing people (Friedman, 1991).

In this research, support culture is associated with neither self-efficacy nor burnout. 
Although the correlation analysis revealed that support culture was positively related to self-efficacy and negatively related to burnout, in the model, support culture did not have any associations. It may be due to the fact that the correlation between support culture and these variables is weak.

Overall, concerning the causal model hypothesized, the results obtained for secondary middle school teachers revealed the relationships expected among variables. In that, school culture dimensions namely bureaucratic culture and task culture can be regarded as important predictors of efficacy for student engagement. Furthermore, efficacy for student engagement can be seen as an important predictor of burnout. But the predictive power of variables was found to be low in explaining variance in burnout. This result shows that professional exhaustion is explained by other variables than these two variables.

Thus, the findings of this study revealed that in order to decrease burnout, one should focus on school culture dimensions such as success/bureaucratic culture and self-efficacy. In other words, school culture dimensions can be regarded as important predictors of self-efficacy and burnout. The findings have indicated that in order to increase self-efficacy, one should focus on school culture dimensions such as bureaucratic and task culture. These school culture dimensions can be seen as important predictors of self-efficacy and burnout.

\section{Strength and Limitations}

As in all studies, there are some strengths and weaknesses in this study. The strength of this study is the test school culture, self-efficacy and burnout within a model which can contribute to the literature theoretically. Also, teachers from all types of middle schools in the Turkish education system are included in the study, which contributes to the generalizability of the results.

On the other hand, there are some limitations in this study. Firstly, this study was conducted with Turkish teachers. Since there are only a few studies on this subject, it was difficult to compare the findings in this study with the findings obtained in other cultures. Secondly, in this study, quantitative techniques were used to analyze the data. For this reason, conducting an in-depth analysis of the main predictors of school culture, self-efficacy and burnout was not possible. In order to overcome this constraint, qualitative and quantitative techniques may be used together in further studies. Lastly, in this study, self-efficacy was measured from the teachers' own perspectives. However, people may not be objective while evaluating themselves. In the future, in order to overcome this limitation, principals, parents, students, and other employees in contact with the teacher may be asked to fill in the scales. Determining the self-efficacy levels by considering the ideas of others would give a more accurate idea.

\section{Conclusion}

The results of this study indicate that school culture dimensions are important predictors of self-efficacy and burnout. More specifically, the findings have shown that the school culture dimensions of success and bureaucratic culture are significantly associated with the burnout dimension of depersonalization. In addition, success culture and efficacy for student engagement are significantly associated with emotional exhaustion. Bureaucratic culture and task culture are significantly associated with efficacy for student engagement and efficacy for instructional strategies. Task culture is also significantly associated with efficacy for classroom management. 
A study on the burnout syndrome and on its contributions in educational field is important, since a better understanding of the burnout syndrome may provide information to teachers, school administrators and politicians about major contributors to burnout. Hence, teachers can exert great efforts to improve their ability to cope with the sources of stress. School administrators and politicians might learn the practical needs of teachers, take necessary measures and provide adequate resources for teachers in order to prevent burnout. Moreover, school administrators shall comprehend the significance of organizational culture in self-efficacy and burnout.

The current study has both theoretical and practical importance, thereby contributing to the literature of psychology and sociology. It points out the importance of studying school culture and burnout in the context of self-efficacy perspective. This study can be considered an attempt to show the association among school culture, self-efficacy and burnout. The present study extends prior work on burnout by addressing school culture and self-efficacy from psychological and sociological perspective.

The model identified and tested in this study can be retested by taking other important psychological phenomena in organizations as dependent variables, such as organizational cynicism, organizational effectiveness and absenteeism.

Authors' ORCID
Meral Öztürk
https://orcid.org/0000-0001-7570-5361
Meryem Berrin Bulut
https://orcid.org/0000-0001-8476-8700
Murat Yildiz
https://orcid.org/0000-0003-3053-4110

\section{References}

Baker, A. B., \& Schaufeli, W. B. (2000). Burnout contagion processes among teachers. Journal of $A p$ plied Social Psychology, 30, 2289-2308. https:// doi.org/10.1111/i.1559-1816.2000.tb02437.x

Balay, R., \& Ipek, C. (2010). Teachers' perception of organizational culture and organizational commitment in Turkish primary schools. Zeitschrift für die Welt der Türken, 2(1), 363-384.

Bandura, A. (1993). Perceived self-efficacy in cognitive development and functioning. Educational Psychologist, 28(2), 117-148. https://doi. org/10.1207/s15326985ep2802 3

Bandura, A. (1994). Self-efficacy. In V. S. Ramachaudran (Ed.), Encyclopedia of human behavior (Vol. 4, pp. 71-81). New York: Academic Press. (Reprinted in H. Friedman [Ed.], Encyclopedia of mental health. San Diego: Academic Press, 1998).

Bandura, A. (1995). Self-efficacy in changing societies. Cambridge: Cambridge University Press.

Bandura, A. (1997). Self-efficacy: The exercise of control. New York: W. H. Freeman and Company.

Bentler, P. M., \& Weeks, D. G. (1980). Lineer structural equations with latent variables. Psychometrika, 45(3), 289-308.

Brouwers, A., \& Tomic, W. (2000). A longitudinal study of teacher burnout and perceived self-efficacy in classroom management. Teaching and Teacher Education, 16(2), 239-253. https://doi. org/10.1016/S0742-051X(99)00057-8

Burke, R. J., \& Greenglass, E. (1993). Work stress, role conflict, social support, and psychological burnout among teachers. Psychological Reports, 73(2), 371-380. https://doi.org/10.2466/ pr0.1993.73.2.371

Cherniss, C. (1993). Role of professional self-efficacy in the etiology and amelioration of burnout. In W. B. Schaufeli, C. Maslach, \& T. Marek (Eds), Professional burnout (pp. 135150). Washington, DC: Taylor \& Francis.

Chesnut, S. R., \& Cullen, T. A. (2014) Effects of self-efficacy, emotional intelligence, and perceptions of future work environment on preservice teacher commitment. The Teacher Educator, 49(2), 116-132. https://doi.org/10.1080/08878 $\underline{730.2014 .887168}$ 
Cloutier, R. (1994). Ergenlik psikolojisinde kuramlar. [Theories de l'adolescence] (Çev. B. Onur). Ankara Üniversitesi Eğitim Bilimleri Fakültesi Dergisi, 27(2), 875-904.

Coladarci, T. (1992). Teachers' sense of efficacy and commitment to teaching. Journal of Experimental Education, 60, 323-337. https://doi.org/10.1 080/00220973.1992.9943869

Dimitrios, B., \& Konstantinos, V. (2014). Organizational culture and job burnout - a review. International Journal of Research in Business Management, 2(1), 43-62.

Farber, B. A. (1990). Burnout in psychotherapists: Incidence, types, and trends. Psychotherapy in Private Practice, 8, 35-44. https://doi. org/10.1300/J294v08n01 07

Friedman, I. A. (1991). High- and low-burnout schools: School culture aspects of teacher burnout. The Journal of Educational Research, 84(6), 325-333. https://doi.org/10.1080/00220671.19 $\underline{91.9941813}$

Gist, M. E., \& Mitchell, T. R. (1992). Self-efficacy: A theoretical analysis of its determinants and malleability. Academy of Management Review, 17, 183-211. https://doi.org/10.2307/258770

Grayson, J. L., \& Alvarez, H. K. (2008). School climate factors relating to teacher burnout: $A$ mediator model. Teaching and Teacher Education, 24, 1349-1363. https://doi.org/10.1016/i. tate.2007.06.005

Guenther, B. J. (2014). Teacher self-efficacy and its relationship to teachers' perceptions of their working conditions. University of Saskatchewan, College of Graduate Studies and Research, Canada.

Guglielmi, R. S., \& Tatrow, K. (1998). Occupational stress, burnout, and health in teachers: A methodological and theoretical analysis. Review of Educational Research, 68, 61-99. https://doi. org/10.2307/1170690

Gündüz, B. (2006). The prediction of teachers burnout according to the irrational beliefs and vocational and personal variables. Türk Psikolojik Danışma ve Rehberlik Dergisi, 3(26), 30-49.

Haghani, M., Bahrami, P., \& Sarkhosh, S. (2011). The relationship among organizational culture and occupational burnout in personnel of TVTO organization, Arak City. Journal of Educational and Management Studies, 2(4), 89-96.
Huberman, A. M., \& Vandenberghe, R. (1999). Introduction - Burnout and the teaching profession. In R. Vandenberghe \& A. M. Huberman (Eds.), Understanding and preventing teacher burnout: A sourcebook of international research and practice (pp. 1-12). Cambridge: Cambridge University Press.

Jennett, H. K., Harris, S. L., \& Mesibov, G. B. (2003). Commitment to philosophy, teacher efficacy, and burnout among teachers of children with autism. Journal of Autism and Developmental Disorders, 33(6), 583-593. https://doi. org/10.1023/B:JADD.0000005996.19417.57

Johnson, S., Cooper, C. L., Cartwright, S., Donald, I., Taylor, P., \& Millet, C. (2005). The experience of work-related stress across occupations. Journal of Managerial Psychology, 20(2), 179-87. https://doi.org/10.1108/02683940510579803

Kaplan, L. S., \& Owings. W. A. (2013). Culture reboot: Reinvigorating school culture to improve student outcomes. 1st ed. California: Corwin.

Kelleci, M. (2008). The effects of Internet use, cell phones and computer games on mental health of children and adolescents. TAF Preventive Medicine Bulletin, 7(3), 253-256.

Kılıç, T., Seymen, O. A., \& Grobowski, W. (2014). Effects of personality factors and organizational culture on the individual and collective efficacy. Conference: The Eighth International Conference on Healthcare Systems and Global Business Issues, Grantham 2014 At: Harlaxton, Grantham, England.

Kılınç, A. Ç., Koşar, S., Er, E., \& Öğdem, Z. (2016). The relationship between bureaucratic school structure and teacher self-efficacy. McGill Journal of Education, 51(1), 615-632. https://doi. org/10.7202/1037362ar

Kokkinos, C. M. (2007). Job stressors, personality and burnout in primary school teachers. British Journal of Educational Psychology, 77, 229243. https://doi.org/10.1348/000709905X90344

Korkmaz, M., \& Çevik, M. S. (2017). Analysis of the relation between organizational culture and alienation in secondary educational institutions. Kuram ve Uygulamada Eğitim Yönetimi, 23(4), 675-716. https://doi.org/10.14527/ kuey.2017.021

Kyriacou, C. (1998). Teacher stress: Past and present. In J. Dunkam \& V. Varma (Eds.), Stress in 
teachers: Past, present and future (pp. 1-13). London: Whurr.

Kyriacou, C. (2000). Stress-busting for teachers. Cheltenham: Stanley Thornes.

Kyriacou, C. (2001). Teacher stress: Directions for future research. Educational Review, 53(1), 27-35. https://doi.org/10.1080/00131910120033628

Li, A., \& Bagger, J. (2008). Role ambiguity and self-efficacy: The moderating effects of goal orientation and procedural justice. Journal of Vocational Behavior, 73, 368-375. https://doi. org/10.1016/i.jvb.2008.07.008

Luszczynska, A., Scholz, U., \& Schwarzer, R. (2005). The general self-efficacy scale: Multicultural validation studies. Journal of Psychology, 139, 439-457. https://doi.org/10.3200/JRLP.139.5.439-457

Maslach, C., \& Jackson, S. E. (1981). The measurement of experienced burnout. Journal of Occupational Behavior, 2, 99-113. https://doi. org/10.1002/job.4030020205

Maslach, C., \& Jackson, S. E. (1986). Maslach Burnout Inventory. Palo Alto, CA: Consulting Psychologist Press.

Maslach, C., Jackson, S. E., \& Leiter, M. P. (1996). Maslach Burnout Inventory Manual. 3rd ed. Palo Alto, CA: Consulting Psychologists Press.

Maslach, C. \& Leiter, M. P. (1999). Teacher burnout: A research agenda. In R. Vandenberghe \& A. M. Huberman (Eds.), Understanding and preventing teacher burnout: A sourcebook of international research and practice (pp. 295-303). Cambridge: Cambridge University Press.

Maslach, C., \& Schaufeli, W. B. (1993). Historical and conceptual development of burnout. In W. B. Schaufeli, C. Maslach, \& T. Marek (Eds.), Series in applied psychology: Social issues and questions. Professional burnout: Recent developments in theory and research (pp. 1-16). Taylor \& Francis.

McCarthy, C. J., Lambert, R. G., O’Donnell, M., \& Melendres, L. T. (2009). The relation of elementary teachers' experience, stress, and coping resources to burnout symptoms. Elementary School Journal, 109(3), 282-300.

McGuire, W. H. (1979). Teacher burnout. Today's Education, 68(4), 5-7.

Mojsa-Kaja, J., Golonka, K., \& Marek, T. (2015). Job burnout and engagement among teachers - Work life areas and personality traits as pre- dictors of relationships with work. International Journal of Occupational Medicine and Environmental Health, 28(1), 102-119. https://doi. org/10.13075/ijomeh.1896.00238

Peterson, K. D. (2002). Enhancing school culture: Reculturing schools. Journal of Staff Development, 23(3), 1-6.

Pines, A., \& Aronson, E. (1988). Career burnout: Causes and cures. New York: Free Press.

Pyc, L. S., Meltzer, D. P., \& Liu, C. (2016). Ineffective leadership and employees' negative outcomes: The mediating effect of anxiety and depression. International Journal of Stress Management, 24(2), 196-215. https://doi.org/10.1037/ str0000030

Rahiem, H. M. D., Abdullah, N. S. M., \& Rahim, H. (2012). School culture and the moral development of children. International Proceedings of Economics Development and Research, 56(23), 114-118. doi: 10.7763/IPEDR

Roloff, M. E., \& Brown, L. A. (2011). Extra-tole time, burnout and commitment: The power of promises kept. Business Communication Quarterly, 74(4), 450-474. https://doi.org/10.1177/1080569911424202

Savaş, A. C., Bozgeyik, Y., \& Eser, i. (2014). A study on the relationship between teacher self-efficacy and burnout. European Journal of Educational Research, 3(4), 159-166.

Schwarzer, R., \& Greenglass, E. (1999). Teacher burnout from a social-cognitive perspective: A theoretical position paper. In R. Vandenberghe \& A. M. Huberman (Eds.), Understanding and preventing teacher burnout: A sourcebook of international research and practice (pp. 238-246). Cambridge: Cambridge University Press.

Sesadri, B., \& Gloryson, C. R. B. (2013). Impact of organizational culture and structure on organizational commitment and individual performance: Mediating role of self-efficacy. 3rd Biennial Conference of the Indian Academy of Management, 12-14 December.

Schaufeli, W. B., \& Enzman, D. (1998). The burnout companion to study \& practice. London: Taylor \& Francis.

Schaufeli, W. B., Leiter, M. P., \& Maslach, C. (2009). Burnout: 35 years of research and practice. $\mathrm{Ca}$ reer Development International, 14(3), 204-220.

Schonfeld, I. W. (2001). Stress in 1st-year women teachers: The context of social support and 
coping. Genetic, Social, and General Psychology Monographs, 127(2), 133-168.

Schwarzer, R., \& Greenglass, E. (1999). Teacher burnout from a social-cognitive perspective: A theoretical position paper. In R. Vandenberghe \& A. M. Huberman (Eds.), Understanding and preventing teacher burnout (pp. 238-246). Cambridge, UK: Cambridge University Press.

Schwarzer, R., \& Hallum, S. (2008). Perceived teacher self-efficacy as a predictor of job stress and burnout: Mediation analyses. Applied Psychology, 57, 152-171. https://doi.org/10.1111/ j.1464-0597.2008.00359.x

Shoji, K., Cieslak, R., Smoktunowicz, E., Rogala, A., Benight, C. C., \& Luszczynska, A. (2015). Associations between job burnout and self-efficacy: A meta-analysis. Anxiety, Stress, \& Coping, 29(4), 1-20. https://doi.org/10.1080/10615806.2015. 1058369

Sinden, J. E., Hoy, W. K., \& Sweetland, S. R. (2004). An analysis of enabling school structure. Journal of Educational Administration, 42(4), 462-478. https://doi.org/10.1108/09578230410544071

Skaalvik, E. M., \& Skaalvik, S. (2009). Does school context matter? Relations with teacher burnout and job satisfaction. Teaching and Teacher Education, 25, 518-524. https://doi.org/10.1016/i. tate.2008.12.006

Skaalvik, E. M., \& Skaalvik, S. (2010). Teacher self-efficacy and teacher burnout: A study of relations. Teaching and Teacher Education, 26(4), 10591069. https://doi.org/10.1016/i.tate.2009.11.001

Skaalvik, E. M., \& Skaalvik, S. (2011). Teacher job satisfaction and motivation to leave the teaching profession: Relations with school context, feeling of belonging, and emotional exhaustion. Teaching and Teacher Education, 27(6), 1029-1038. https://doi.org/10.1016/i.tate.2011.04.001

Smetackova, I. (2017). Self-efficacy and burnout syndrome among teachers. The European Journal of Social and Behavioural Sciences, 20(3), 2476-2478. http://dx.doi.org/10.15405/ejsbs.219
Sottile, J., Carter, W., \& Murphy, R. (2002). The influence of self-efficacy on school culture, science achievement, and math achievement among inservice teachers. Paper presented at the Annual Meeting of the American Educational Research Association (New Orleans, LA, April 1-5, 2002).

Stoeber, J., \& Rennert, D. (2008). Perfectionism in school teachers: Relations with stress appraisals, coping styles, and burnout. Anxiety, Stress, \& Coping. An International Journal, 21(1), 37-53. https://doi.org/10.1080/10615800701742461

Terzi, A. R. (2005). Organizational culture in primary schools. Kuram ve Uygulamada Eğitim Yönetimi, 43, 423-442.

Tomić, W., Evers, W., \& Brouwers, A. (2004). Existential fulfillment and teacher burnout. European Psychotherapy, 5(1), 65-73.

Torfi, A., Alam, S., \& Nikbakhsh, R. (2014). The relationship between organizational culture and job burnout in the employees of physical education organization. International Journal of Sport Studies, 4(6), 666-670.

Troman, G., \& Woods, P. (2001). Primary teacher's stress. New York: Routledge.

Wright, T. A., \& Bonett, D. G. (1998). The contribution of burnout to work performance. Journal of Organizational Behavior, 18, 491-499. https://doi. org/10.1002/(SICI)1099-1379(199709)18:5<491::AIDJOB804>3.0.CO;2-I

Yulianti, P., Atomzeal, M. O., \& Arina, N. A. (2018). Burnout, self-efficacy and work satisfaction among special education teacher. In The 2018 International Conference of Organizational Innovation, KnE Social Sciences, pp. 1180-1191. https://doi.org/10.18502/kss.v3i10.3460

Zamini, S., Zamini, S., \& Barzegary, L. (2011). The relationship between organizational culture and job burnout among the professors and employees in the university of Tabriz. Social and Behavioral Sciences, 30, 1964-1968. https://doi. org/10.1016/i.sbspro.2011.10.381 